\title{
More green infrastructure is required to maintain ecosystem services under current trends in land-use change in Europe
}

\author{
Joachim Maes - Ana Barbosa - Claudia Baranzelli - Grazia Zulian • \\ Filipe Batista e Silva · Ine Vandecasteele · Roland Hiederer • Camino Liquete • \\ Maria Luisa Paracchini - Sarah Mubareka - Chris Jacobs-Crisioni • \\ Carolina Perpiña Castillo $\cdot$ Carlo Lavalle
}

Received: 10 March 2014 / Accepted: 8 August 2014/Published online: 20 August 2014

(C) Springer Science+Business Media Dordrecht 2014

\begin{abstract}
Green infrastructure (GI), a network of nature, semi-natural areas and green space, delivers essential ecosystem services which underpin human well-being and quality of life. Maintaining ecosystem services through the development of GI is therefore increasingly recognized by policies as a strategy to cope with potentially changing conditions in the future. This paper assessed how current trends of land-use change have an impact on the aggregated provision of eight ecosystem services at the regional scale of the European Union, measured by the Total Ecosystem Services Index (TESI8). Moreover, the paper reports how further implementation of GI across Europe can help maintain ecosystem services at baseline levels. Current demographic, economic and agricultural trends, which affect land use, were derived from the so called Reference Scenario. This scenario is established by the European Commission to assess the impact of energy and climate policy up to 2050. Under the Reference Scenario, economic growth, coupled with the total population, stimulates increasing urban and industrial expansion. TESI8 is
\end{abstract}

J. Maes $(\bowtie) \cdot$ A. Barbosa · C. Baranzelli ·

G. Zulian - F. Batista e Silva · I. Vandecasteele .

R. Hiederer · C. Liquete · M. L. Paracchini ·

S. Mubareka - C. Jacobs-Crisioni .

C. P. Castillo - C. Lavalle

Institute for Environment and Sustainability, European

Commission - Joint Research Centre, Via Fermi 2749,

21027 Ispra, VA, Italy

e-mail: joachim.maes@jrc.ec.europa.eu expected to decrease across Europe between 0 and $5 \%$ by 2020 and between 10 and $15 \%$ by 2050 relative to the base year 2010. Based on regression analysis, we estimated that every additional percent increase of the proportion of artificial land needs to be compensated with an increase of $2.2 \%$ of land that qualifies as green infrastructure in order to maintain ecosystem services at 2010 levels.

Keywords Ecosystem services · Green infrastructure $\cdot$ Land-use model $\cdot$ Scenario . European Union · Biodiversity strategy

\section{Introduction}

Ecosystems are essential to human well-being (MA 2005). They provide vital goods and services, such as food provision, carbon sequestration and water regulation that support economic prosperity, social wellbeing and quality of life. Biodiversity plays a key role in the structural set-up of ecosystems which is essential to maintaining basic ecosystem processes and supporting ecosystem functions (Cardinale et al. 2011; Mace et al. 2012; Naeem et al. 2012). Consequently many of the pressures that affect habitats and species continue to impact ecosystem services as well. As a result, the maintenance of sustainable provision levels of ecosystem services is becoming a major concern in Europe (Maes et al. 2013a, b). Land use 
change is reported as the single most important driver of biodiversity loss (Foley et al. 2005; Metzger et al. 2006; Geneletti 2012). In turn, land use change is strongly driven by population growth and urbanization processes and the resulting increase in demand for resources such as food and timber as well as space for housing and a myriad of economic activities. At the global level, land conversions occur often at the cost of wild lands such as wetlands, natural areas and seminatural ecosystems (Lambin and Meyfroidt 2011).

One way to protect the natural capital which delivers essential ecosystem services is the conservation of biodiversity using a network of nature reserves, such as the European Union's Natura 2000 network. This network now covers almost $18 \%$ of the EU territory and is reported to deliver ecosystem services worth $€ 300$ billion annually (Ten Brink et al. 2011). If we consider that biodiversity supports the delivery of ecosystem services (Hector and Bagchi 2007; Cardinale 2011; Isbell et al. 2011), ensuring the long term survival of species and habitats that deliver key ecosystem services is, arguably, a good policy strategy. But the services that biodiversity delivers do not stop at the borders of protected areas. Many ecosystem services are generated outside nature reserves. Urban green areas, for example, provide cheap and accessible recreational opportunities to citizens (Gómez-Baggethun and Barton 2013; Lovell and Taylor 2013). Floodplains, often situated on grasslands or pastures, protect people and infrastructure in downstream areas during peak flow events. Forests and woodland help regulate water flows, capture carbon and air pollutants from the atmosphere, and prevent soils from being eroded. Some coastal ecosystems such as natural beaches are among the world's most visited ecosystems and they act as a coastal defence against storms. This network of the green infrastructure (GI) that surrounds us is essential to deliver a wide range of benefits to people. So, too, is maintaining and investing in this network.

GI is an interconnected network of green space that conserves natural ecosystem values and functions and provides associated benefits to human populations (Benedict and MacMahon 2002). Tzoulas et al. (2007) define GI as all natural, semi-natural and artificial networks of multifunctional ecological systems within, around and between urban areas, at all spatial scales. GI includes natural and semi-natural areas, and green spaces in rural and urban, terrestrial, freshwater, coastal and marine areas. However, not all green space qualifies as GI. Two important properties of GI are its internal connectivity and multi-functionality; hence, both terms are common to most definitions of GI (EEA 2011).

The continued and sustainable provision of ecosystem services and the protection of natural capital are increasingly recognized by EU policies as a strategy to cope with potentially changing conditions in the future. In particular the EU biodiversity strategy to 2020 aims under target 2 to maintain and enhance ecosystems and their services by establishing GI and restoring at least $15 \%$ of degraded ecosystems (EC 2011a). At the European scale, the European Commission defines GI as a strategically planned network of natural and seminatural areas with other environmental features designed and managed to deliver a wide range of ecosystem services. It incorporates green spaces (or blue if aquatic ecosystems are concerned) and other physical features in terrestrial (including coastal, urban and rural settings) and marine areas (EC 2012).

This paper assesses the feasibility of reaching target 2 of the EU biodiversity strategy, building on a relation between GI and the delivery of ecosystem services at the regional scale in Europe. A novelty of our approach is the dynamic coupling of ecosystem service indicators with a fine spatial and temporal resolution land use model. This allows us to explore future ecosystem service provision in a spatially explicit manner while taking into account the landuse impacts of ongoing demographic, economic and agricultural developments in Europe. To this end, the paper firstly introduces the European Land Use based Integrated Sustainability Assessment platform (LUISA) and reports on a Reference Scenario, which was established to assess the local land-use impacts of the energy and climate targets in the EU up to 2050. Following the work by Maes et al. (2012) and Dick et al. (2014) we proceed to describe an aggregate ecosystem service index which is made spatially explicit at the European regional scale. This index is based on eight separate indicators for several ecosystem services, and is dynamically coupled to the LUISA. This enables to examine how aggregate ecosystem service supply is expected to change as a result of future land use changes in Europe under reference conditions. Finally we address the question as to how ecosystem service levels can be maintained under a scenario of increasing urbanization in Europe. 


\section{Materials and methods}

Land use modelling platform

LUISA is a dynamic, spatial modelling platform which simulates future land use changes based on biophysical and socio-economic drivers. Its core was initially based on other land use models, namely the Land Use Scanner (Hilferink and Rietveld 1999; Koomen et al. 2011), and the CLUE and DynaCLUE models (Veldkamp and Fresco 1996; Verburg et al. 2006; Verburg and Overmars 2009), but its current form is the result of a continuous development effort by the Joint Research Centre (Lavalle et al. 2011). It essentially downscales aggregate amounts of land use change expected in the future to a fine resolution using suitability maps for different land uses and neighbourhood relationships between land uses. The suitability and neighbourhood parameters are statistically calibrated based on observed land-use patterns.

LUISA has been specifically designed to assess land-use impacts of EU policies. It is meant to provide a vision of possible futures and indicative qualitative and quantitative comparisons between simulated scenarios and policy options at European level. It runs at a spatial resolution of 1 ha. It simulates future spatial patterns of a number of land-use groupings, namely urban areas, industrial and commercial areas, arable land, permanent crops, semi-natural vegetation and forest land.

The platform accommodates multiple policy scenarios in order to represent different facets of EU policy. Often LUISA inherits policy scenarios from other sector models (Fig. 1). For example, land demand for different agriculture commodities is taken from the CAPRI model (Britz and Witzke 2008), which takes on board the effects of the Common Agricultural Policy. The most recent demographic projections from Eurostat are used to derive future demand for additional residential areas in each region. Energy and economic policies are also passed to LUISA through macro-economic models (Lavalle et al. 2013; Batista e Silva et al. 2014), such as the GEM-E3 and PRIMES (EC 2013). Other spatially explicit land-use policies, such as transport improvements or land-use regulations, are configured directly in LUISA (Batista e Silva et al. 2013).
LUISA is structured in three main modules: the land claims module; the land-use allocation module; and the indicator module. Demand for different land uses is defined within the land claims module. A finite range of minimum and maximum number of hectares, required to satisfy demands for each land use for each year and for each NUTS 2 area, is computed using outputs of exogenous models. These land claims are passed onto the land allocation module. The role of this second module is to spatially allocate the land claims for the simulated land-use classes for each region on an annual basis. The allocation is based on the dynamic competition between land uses, which takes into account spatial allocation rules that stem from a combination of land demand, land-use suitability, temporally-dynamic neighbourhood characteristics and scenario/policy-specific decision rules. The third module, within the context of this paper, refers to indicators that compute the provision of ecosystem services (Fig. 1).

\section{A Reference Scenario for land use in Europe}

The definition of the Reference Scenario is given in the Energy Trends to 2030 publication by the directorategeneral for energy and for climate (EC 2010a) and the Impact Assessment, annex to the Energy Roadmap 2050 (EC 2011b), as well as the Roadmap itself (EC 2011c). This definition specifies full implementation of the Climate and Energy package. The legislation included within the Climate and Energy Package reflects the legally binding targets to ensure that the EU meets its climate and energy targets for 2020: $20 \%$ reduction in EU greenhouse gas emissions from 1990 levels; raising the share of EU energy consumption produced from renewable resources to $20 \%$; a $20 \%$ improvement in the EU's energy efficiency (EC 2010b). This scenario assumes that national targets under the Renewables directive (EP 2009a) and the GHG Effort-sharing decision (EP 2009b) are achieved. The policy provisions that are taken into consideration in the implementation of the Reference Scenario in LUISA are: Renewable Energy directive, Common Agricultural Policy, TEN-T Transport Network and EU Biodiversity Strategy which are detailed in Lavalle et al. (2013).

The amount of land claimed for urban fabric is driven by population projections provided by Eurostat 


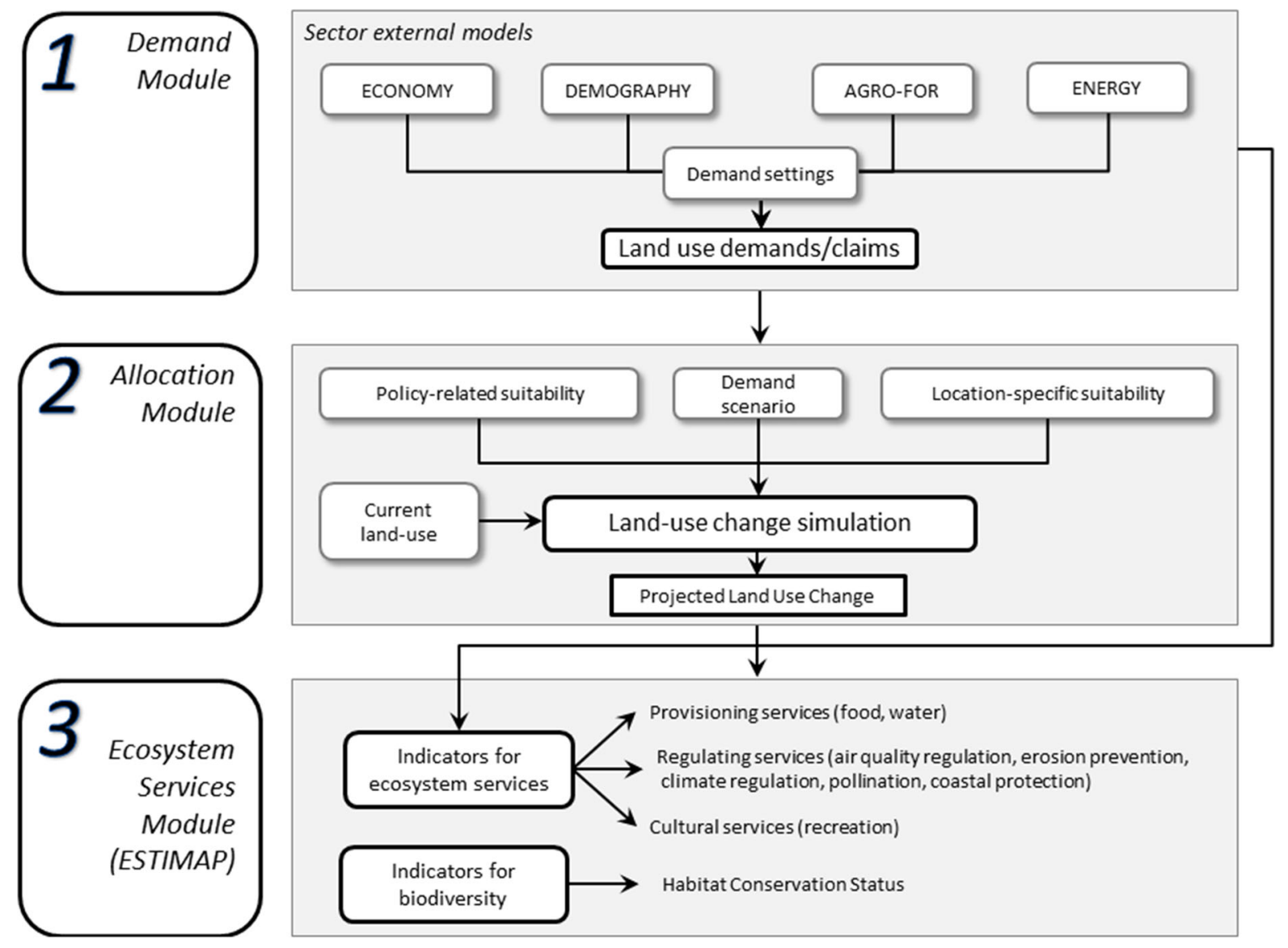

Fig. 1 Flow chart of the coupled land use-ecosystem services model

(EC 2011d), NUTS 2 region-specific trends of urban land used per household, and an assumed general trend of household size decreases. It assumes a total population growth of $4.4 \%$ for the period 2010-2050 in the EU27. Industrial and commercial land requirements are estimated from economic trends, using as a proxy the Gross Value Added (GVA) per sector activity and are computed by GEME3, run by the E3M Lab (National Technical University of Athens). The estimated future forest and agricultural land-use requirements are given by the G4M/GLOBIUM (Böttcher et al. 2012) and the CAPRI (Britz and Witzke 2008) models, respectively. The configuration of the Reference Scenario is described in further detail in Lavalle et al. (2013). The results of the Reference Scenario consist of gridded maps at 1 ha resolution indicating annual land-use patterns, accessibility and population levels for each year between 2007 and 2050.
Assessment of ecosystem services

The projected land use land cover maps as simulated by LUISA for 2010, 2020 and 2050 were subsequently used to assess any changes in ecosystem services. The ecosystem services module of LUISA is called ESTIMAP (Zulian et al. 2013a) and runs a set of spatial operations a Geographical Information System (GIS) environment to calculate the services listed in Table 1. We adhere to the Common International Classification of Ecosystem Services (CICES, http:// www.cices.eu, Haines-Young and Potschin 2013; Maes et al. 2013a, b). CICES provides a framework for classifying ecosystem services that depend on living processes. It is hierarchical in structure, with each level providing a more detailed description of the ecosystem service being considered. The advantage of a hierarchical system is that some commonly used indicators for ecosystem services can be used at the 


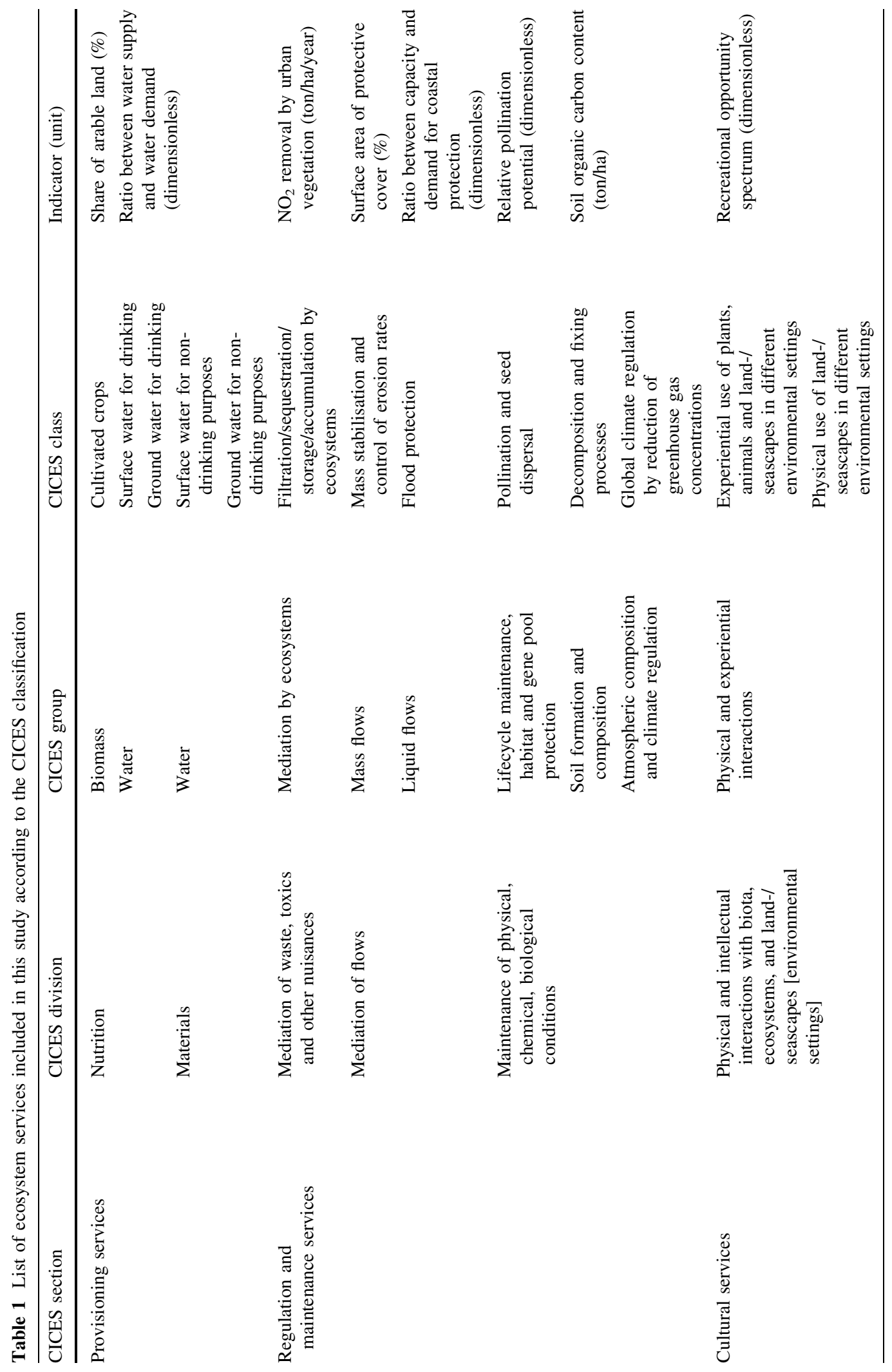


most detailed level while others can represent higher hierarchical levels if no detailed data is available. Table 1 contains the specific indicator that was used to map each service. Hereafter, we briefly summarize the description of each indicator and we include reference material where readers can find more details on the mapping and modelling methodology.

The area of cultivated crops was approximated by the share of arable land. All water provisioning services are estimated by a single index which is based on the ratio between total water supply (Wriedt and Bouraoui 2009) and aggregated water demand by different sectors (Vandecasteele et al. 2014). Total water supply equals rainfall minus evapotranspiration. Following Nowak et al. (2006) and based on the regression models presented in Beelen et al. (2009) we used the total removal of the air pollutant $\mathrm{NO}_{2}$ by urban and peri-urban vegetation as indicator for the mediation of waste, toxics and other nuisances by ecosystems. Increasing urban vegetation corresponding to increased supply, and both higher pollutant concentrations and urbanization, corresponding to an increased demand for cleaner air, result in increased values of this indicator. Erosion control is mapped by assessing the area of protective vegetation, i.e. forests, semi-natural areas and pasture in areas with high erosion risk. Erosion risk was assessed using K-factor, a parameter used to assess soil erodibility (Panagos et al. 2012). Soils with $K$ values $>0.045$ (t ha h)/ (ha $\mathrm{MJ} \mathrm{mm}$ ) are considered sensitive to soil erosion. Increasing protective vegetation increases this indicator. Coastal ecosystems provide different levels of protection against flooding and erosion. We used the ratio between coastal protection capacity and demand for coastal protection as indicator for this service, based on the study by Liquete et al. (2013). Increasing demand, as defined by population and infrastructure, decreases the value of this indicator if capacity is kept constant. Pollination is assessed using the relative pollination potential (Zulian et al. 2013b). We used changes in Soil Organic Carbon stock which is often used as indicator for both climate regulation (carbon stock) and soil formation and composition (Hiederer et al. 2013). Physical and experiential interactions (under CICES division cultural services, Table 1) is approximated by the Recreational Opportunity Spectrum, which combines the recreation potential of land pixels with their accessibility for people (Paracchini et al. 2014).
The unit of assessment is the European NUTS 2 level. The NUTS classification (Nomenclature of territorial units for statistics) is a hierarchical system for dividing up the economic territory of the EU for the purpose of the collection, development and harmonisation of EU regional statistics and of socio-economic analyses of the regions. Following Raudsepp-Hearne et al. (2010) we used administrative boundaries for our assessment, because social processes shape the production and consumption of ecosystem services. This is especially relevant for the LUISA platform which allocates land use based on claims set by economic sectors for which statistics are available at NUTS 2 level. Furthermore, NUTS 2 are directly policy relevant, as EU funding and policies and local as well as regional governance is often defined at NUTS 2 level. In particular the EU's cohesion policy, which is responsible for the main share of the EU's investments in regional economies including the financing of large scale GI projects, needs consistent spatial information at regional scale in order to make decisions on future investments using regional funds. Therefore, we aggregated all results to NUTS 2, using spatial statistics operations provided by a GIS. All other inputs to the ecosystem services maps are kept constant.

\section{Total Ecosystem Services Index}

We aggregated the eight ecosystem services indicators into a single indicator, hereafter referred to as TESI8. This indicator is very similar to other documented aggregate indicators (see Maes et al. 2012; Dick et al. 2014) but differs in that we have only used indicators that are dynamically linked to LUISA. The Total Ecosystem Service Index (TESI8) is the sum of eight normalised values (between 0 and 1) of each ecosystem service amount in each NUTS 2 unit using the following formula:

$E S_{\text {norm }}=\left(\frac{x_{E S}-x_{\min }}{x_{\max }-x_{\min }}\right)$,

where $\mathrm{ES}_{\text {norm }}$ is the normalised value of the ecosystem service for each NUTS2 area, $\mathrm{X}_{\mathrm{ES}}$ is the (original) value of the ecosystem service, $X_{\min }$ is the lowest value of $X_{E S}$ at any NUTS2 area, and $X_{\max }$ is the highest value of $X_{\mathrm{ES}}$ at any NUTS2 area. TESI8 is calculated by summing the normalized values per ecosystem service, which effectively gives equal weight to each service within the total index. 
Table 2 Typology of the land use modelling platform and inclusion (yes/no) of land classes in the dynamic loop of the model

\begin{tabular}{|c|c|c|c|c|c|c|}
\hline Land use level 1 & Land use level 2 & $\begin{array}{l}\text { Modelled } \\
\text { classes }\end{array}$ & GI category & 2010 & 2020 & 2050 \\
\hline \multirow[t]{3}{*}{ Artificial land use } & Urban & Yes & Never & 3.81 & 3.95 & 4.25 \\
\hline & Industry & Yes & Never & 0.72 & 0.78 & 0.94 \\
\hline & Infrastructure & Yes & Never & 0.37 & 0.37 & 0.37 \\
\hline \multirow[t]{7}{*}{ Agriculture } & Permanent crops & Yes & GI only if HNV & 3.04 & 3.00 & 2.83 \\
\hline & Cereals & Yes & Never & 11.08 & 11.19 & 9.10 \\
\hline & Maize & Yes & Never & 3.22 & 3.23 & 2.68 \\
\hline & Root crops & Yes & Never & 0.88 & 0.65 & 0.59 \\
\hline & New energy crops & Yes & Never & 0.00 & 1.21 & 3.32 \\
\hline & Other arable & Yes & Never & 18.70 & 17.48 & 16.99 \\
\hline & Pastures & Yes & GI only if HNV & 10.02 & 9.71 & 9.45 \\
\hline \multirow[t]{3}{*}{ Forests and semi-natural areas } & Forests & Yes & GI & 33.28 & 34.08 & 35.46 \\
\hline & Semi-natural vegetation & Yes & GI & 3.62 & 3.05 & 2.65 \\
\hline & Other nature & No & GI & 6.61 & 6.61 & 6.61 \\
\hline \multirow[t]{2}{*}{ Water } & Wetlands & No & GI & 2.09 & 2.09 & 2.09 \\
\hline & Water bodies & No & GI & 2.55 & 2.55 & 2.55 \\
\hline \multirow[t]{5}{*}{ Abandoned land } & Abandoned arable land & Yes & Never & $<0.01$ & $<0.01$ & $<0.01$ \\
\hline & Abandoned permanent crops & Yes & GI & $<0.01$ & $<0.01$ & $<0.01$ \\
\hline & Abandoned pastures & Yes & GI & $<0.01$ & $<0.01$ & $<0.01$ \\
\hline & Abandoned urban & Yes & Never & $<0.01$ & 0.04 & 0.11 \\
\hline & Abandoned industry & Yes & Never & 0.01 & 0.01 & $<0.01$ \\
\hline
\end{tabular}

HNV High Nature Value farmland

Relative share (\%) of land cover/land use classes in EU-28 according to the simulated reference scenario for 2010,2020 and 2050

As such, the TESI8 index reflects the average level of provision of the ecosystem services present in each region. More than an absolute quantification of the ES provisioning levels, the TESI enables a quick, qualitative comparison of the ES provision between regions of the EU.

\section{Assessment of green infrastructure}

Generally, two main GI components are identified: cores and links (Lafortezza et al. 2013). Here, we used the GUIDOS software (Vogt 2012) to assess the total coverage $\left(\mathrm{km}^{2}\right)$ of each NUTS 2 area by a green infrastructure network in terms of core areas and links.

The choice of the land-use classes to include in the assessment of GI components depended on the landuse typology used in LUISA (Table 2). For this study, permanent crops and pastures were identified as GI if they were within an area considered to be "High Natural Value Farmland" (Paracchini et al. 2008). The High Nature Value Farmland map comes from a growing recognition that the conservation of biodiversity in Europe depends on the continuation of lowintensity farming systems. Land abandonment leads to changes in vegetation and in the landscape. In the long term, if the land is left unmanaged, it is expected to turn into forest (Benjamin et al. 2005). For this reason, abandoned permanent crops and pastures are considered a component of the GI, assuming they will remain abandoned. In contrast, abandoned arable land is not considered as a GI component. Land abandonment is indeed reported to bring negative and abrupt changes on the provision of ecosystem services as well e.g. in semi-arid rural landscapes (García-Llorente et al. 2012). LUISA does at present not provide a more detailed typology of agricultural land use to account for regional differences in Europe so the present allocation of abandoned land to GI is the best available compromise. Forest and semi-natural vegetation, wetlands, water and other natural habitats (glaciers, sand dunes and beaches) are also identified as GI although within LUISA some of these classes are not 
simulated (see Table 2) and thus remain static over time.

Data analysis

We assessed the relationship between multi-functionality (defined as the number of ecosystem services delivered per region) and the total supply of ecosystem services, measured by TESI8. To assess multi-functionality, we counted per region the number of individual services of which the standardized score was above the 50th or the 75th percentile. For example, the 50th percentile is the value below which $50 \%$ of the observations is found.

Changes in the projected value of TESI8 for 2020 and 2050 were assessed relative to the value of TESI8 in 2010 using the following formula:

$\delta=\left(\frac{T E S I 8_{t}-T E S I 8_{2010}}{T E S I 8_{2010}}\right) \times 100$,

where $\delta$ is the relative change $(\%)$ and TESI $8_{\mathrm{t}}$ is the value for TESI8 in 2020 or 2050.

We assessed the relationship between TESI8, the relative share of green infrastructure (GI, \%) and the relative share of artificial land use (AS, \%) at NUTS 2 scale using multiple linear regression:

TESI8 $=a+b \times G I-c \times A S$,

where $a, b$ and $c$ are regression coefficients. AS is the sum of all artificial area including urban, industrial and commercial land use as well as infrastructures. Equation 3 assumes that every increase of artificial land results in a decrease of TESI8 while an increase in GI results in an increase of TESI8.

Target 2 of the EU biodiversity strategy aims to maintain (and enhance) ecosystem services by 2020 . Using the coefficients of Eq. 3, we calculated the total area of land covered by green infrastructure $\mathrm{AGI}_{\text {tot }}$ $\left(\mathrm{km}^{2}\right)$ which is needed to offset urban expansion to keep TESI8 constant. This area corresponds to:

$$
\begin{aligned}
& A G I_{\text {tot }} \\
& =\sum_{i}\left[\frac{\left(G I_{i, 2010}+\frac{c}{b} \times\left(A S_{i, 2020}-A S_{i, 2010}\right)-G I_{i, 2020}\right)}{100}\right] \\
& \quad \times A_{i},
\end{aligned}
$$

where $\mathrm{GI}_{\mathrm{i}, 2010}(\%)$ and $\mathrm{GI}_{\mathrm{i}, 2020}(\%)$ represent the relative area of green infrastructure in NUTS 2 region $\mathrm{i}$ in 2010 and 2020, respectively; $\operatorname{AS}_{\mathrm{i}, 2010}(\%)$ and
$\mathrm{AS}_{\mathrm{i}, 2020}(\%)$ represent the relative area of artificial land in NUTS 2 region $\mathrm{i} ; \mathrm{A}_{\mathrm{i}}\left(\mathrm{km}^{2}\right)$ is the total surface area of NUTS 2 region $\mathrm{i}$. The ratio $\mathrm{c} / \mathrm{b}$ which is derived from Eq. 3 corresponds to the relative increment in green infrastructure (\%) which is required to offset urban expansion in order to maintain the value of TESI8 constant over time at EU scale. Negative values for the numerator of Eq. 4 are set to 0 . This occurs in NUTS 2 areas where for instance net afforestation is higher than net urban expansion. This avoids GI offsetting between regions with a surplus in GI and regions with a deficit in GI.

\section{Results}

Changes in land use and green infrastructure under the Reference Scenario

Under the Reference Scenario, economic growth, coupled to population growth, stimulates urban and industrial expansion (Table 2; Fig. 2). Simultaneously, the net surface area of land covered by forests continues to grow in Europe, in response to increased demand for energy from biomass and land abandonment processes. This takes place partially at the cost of semi-natural areas. Agricultural land is expected to undergo changes as well, stimulated by an increased demand for biofuels. In general, arable land and pasture are expected to decrease but the portion of arable land for the cultivation of new energy crops is expected to increase.

The GI network in Europe is expected to expand in area by $0.2 \%$ by 2020 and $1.1 \%$ by 2050 , mainly as a result of net afforestation. In absolute terms this corresponds to an increment of $9,421 \mathrm{~km}^{2}$ in 2020 and $47,393 \mathrm{~km}^{2}$ in 2050 , respectively.

Impact of land-use change on ecosystem services

We used the simulated 2010 land use/cover data as baseline to map TESI8 per NUTS2 area in the EU (Fig. 3). Regions with a lower than average TESI8 value coincide with areas where land is predominantly covered by urban fabric and intensive crop production. Regions with a high proportion of forests and wetlands usually result in TESI8 values that are higher than average. Dryer areas, where grasslands or shrub are dominant in the landscape but where also important 
Fig. 2 Change in relative land cover and land use (\%) in the EU according to the reference scenario

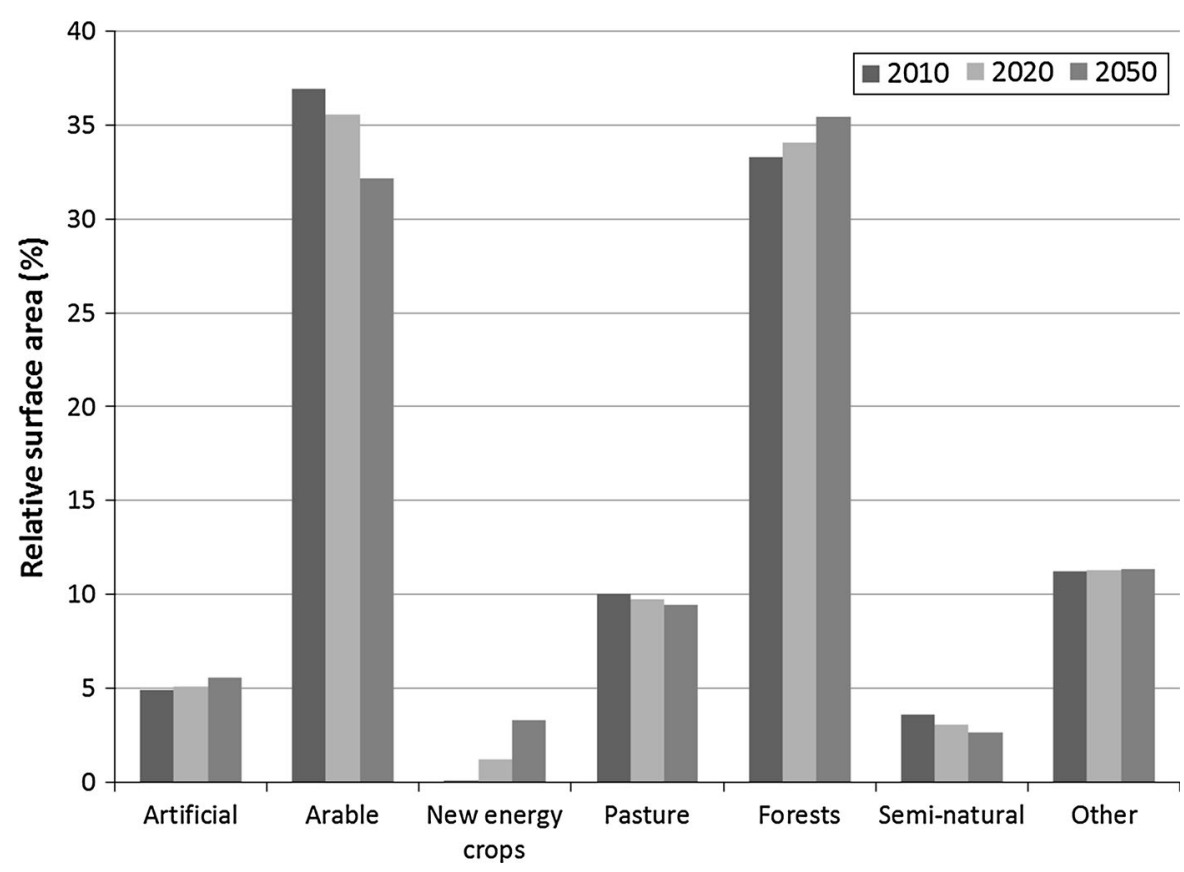

agricultural activities take place, are characterized by lower TESI8 values. This is particularly evident for regions in Hungary and Romania as well as in some regions across the Mediterranean which are known to be affected by water stress. Coastal protection against sea-born storms is only delivered by coastal ecosystems and thus increases the TESI8 of coastal regions relative to landlocked regions. Erosion protection is only provided by vegetation in areas with a medium to high erosion risk, mostly in regions with an important share of arable land on slopes and relatively high rainfall rates. Air quality regulation is deliberately restricted to large urban zones and as a consequence, regions which contain significant patches of urban trees contribute more to the final TESI8 value.

High values of TESI8 are positively correlated to multi-functionality or the capacity of an area to provide multiple services (Fig. 4). Multi-functionality was calculated by counting the number of services which a region supplies relative to the other regions in Europe making use of percentiles scores. Regions which provide one or two services exhibit lower TESI8 values than regions which provide more services. In the discussion we relate this observation to the assessment of trade-offs among ecosystem services.

Figures 5 and 6 report the relative change in TESI8 with respect to the Reference Scenario for land-use change, keeping other input variables to TESI8 constant. By 2020, TESI8 is expected to decrease across Europe between 0 and $5 \%$ relative to 2010. A few exceptions are most regions in The Netherlands, the Scottish Highlands and south-east Croatia where TESI8 is expected to increase. By 2050, more pronounced losses in TESI8 are expected with relative declines of between 10 and $15 \%$ in substantial parts of Europe. Only in the south-eastern part of the Netherlands, TESI 8 would slightly increase by about $1 \%$.

These results suggest that the expected growth of land that qualifies as GI is insufficient to maintain TESI8 at the level of 2010 since the expansion rate of artificial land use is higher than the relative growth of GI. As a result, TESI8 is expected to decline (Fig. 7). Aggregated at the EU level, the loss in TESI8 by 2020 was estimated at $1.6 \%$ relative to 2010 , while in 2050 an overall loss of $5.2 \%$ is expected if land-use trends continue as set by the Reference Scenario.

The relationship between TESI8, the share of artificial land and the share of GI was modelled using multiple linear regression on the data per NUTS 2 region for the base year 2010. Table 3 lists the regression coefficients and the model diagnostics. The model yielded significant regression coefficients. As expected, TESI8 is positively associated with the share of GI (Fig. 8) while it is negatively associated with the share of artificial area in a NUTS region 


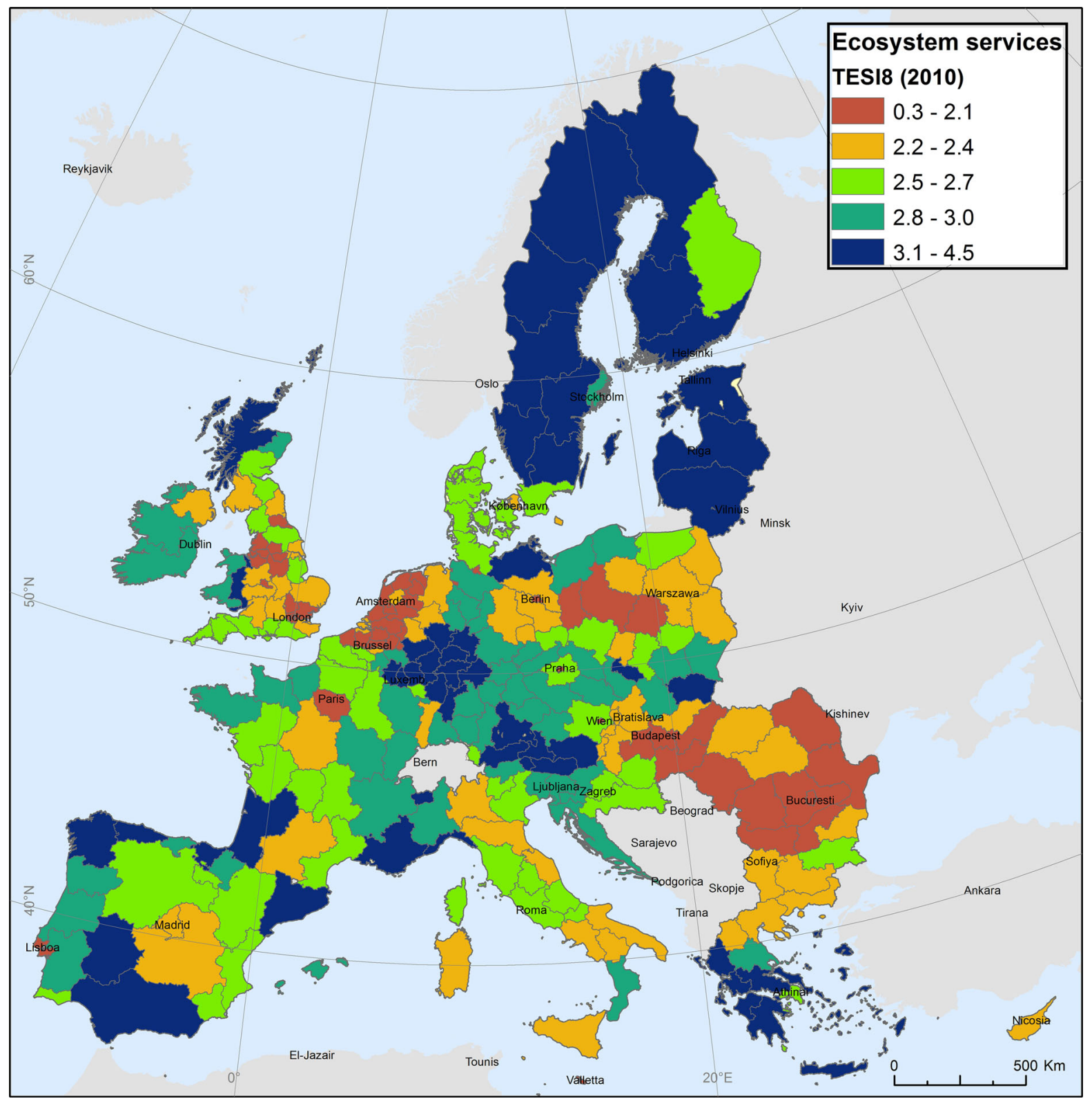

Fig. 3 Spatial pattern of the total ecosystem services index (TESI8) based on the sum of eight standardized ecosystem services indicators

(Fig. 9). The ratio between the regression slopes suggests that a $1 \%$ increase in the share of land covered by artificial land needs be supplemented by a $2.2 \%$ increase in the share of GI in order to keep TESI8 at 2010 levels. It follows that in addition to the expected increment of GI under the Reference Scenario, $19155 \mathrm{~km}^{2}$ of land will need to be converted to GI to maintain ecosystem services in the EU at 2010 levels.

\section{Discussion}

General findings

Two important observations can be obtained from this study. Firstly, GI enhances the delivery of multiple ecosystem services at the regional scale in the EU. Regions where more land is covered by GI provide more services at higher aggregated quantity. GI 


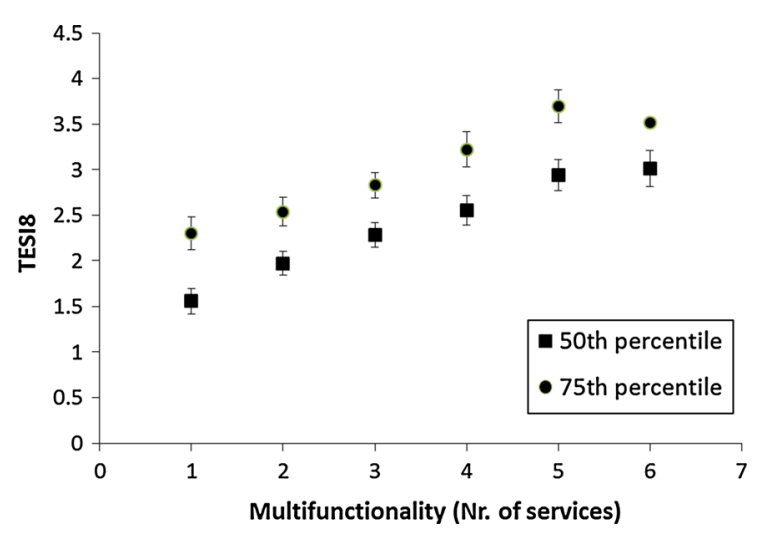

Fig. 4 Relation between the number of services and the total ecosystem services index (TESI8) based on the sum of eight standardized ecosystem services indicators. The number of services in every region was calculated by including ecosystem services which delivered values that are higher than 50 and $75 \%$ of the observations, respectively

influences the capacity of ecosystems to provide services across a range of scales. For cities, within the context of urban planning and urban ecology, there is a vast body of literature about the potential benefits of designed urban green space or urban green infrastructure to provide ecosystem services to citizens (e.g. Pataki et al. 2011). In rural areas, GI includes nature reserves, parks and open spaces, forests and farmlands and provides thus the links which binds ecosystems together, facilitating the flow of ecological processes (Lafortezza et al. 2013), and hence, ecosystem services.

The second and more important observation of this study is that, given the assumptions of our integrated modelling approach, maintaining ecosystem services as proposed under Target 2 of the EU biodiversity strategy, requires expanding the network of green infrastructure and (or) increasing the efficiency of artificial land use by urbanization for instance, by promoting a more compact design of cities. If cities expand under the assumptions of the Reference Scenario maintaining ecosystem services requires growth in green infrastructure at a rate which doubles the growth rate of artificial land use. Urbanization of a given region results in a supply fall of ecosystem services due to soil sealing while at the same time the demand for ecosystem services rises by the increasing numbers of urban dwellers.

One possible argument against our conclusion is that the aggregated indicator we used in this study, TESI8, does not sufficiently represent the full array of ecosystem services that is provided, nor that it sufficiently reflects the trade-offs that may exist among ecosystem services. Synergies and trade-offs among ecosystem services at EU scale are analysed in Maes et al. (2012). At European scale, the production of crops and livestock is negatively correlated to other ecosystem services. Regulating services mostly occur in two separate bundles. Landscapes that are mostly covered by forests deliver mainly carbon storage, air quality regulation, protection against soil erosion, and recreation. Landscapes where open water and wetlands predominate are evidently important providers of water and water regulating services; they also maintain important carbon stocks in form of organic material. Clearly, enhancing some services such as food and timber production inevitably results in losses of other services. These trade-offs cannot be captured fully by a single, aggregate statistic. For this reason, Dick et al. (2014) used separate TESI values for delivering regulating and cultural ecosystem services, aside from an aggregate TESI in a cross-scale assessment of ecosystem services in 11 sites of the Environmental Change Network in the UK. Yet, here we argue that TESI is useful to assess at broad scale whether or not ecosystem services are maintained or lost. The positive relationship between the number of ecosystem services that are provided by a single region and the total aggregated sum of these services reflected by TESI gives confidence in our approach. European regions which deliver few services have significantly lower TESI values than regions where multiple services are provided. We conclude that the particular construction of TESI8 as a sum of standardized scores of individual ecosystem services effectively indicates both multi-functionality and total supply and is thus useful to measure progress to target 2 of the biodiversity strategy.

Implications of a European GI network that complies with the biodiversity strategy

We have seen that, apart from the expected increment of GI under the Reference Scenario, Europe would need to expand the GI network by about $20,000 \mathrm{~km}^{2}$ of land to maintain ecosystem services at 2010 levels. Implementing several tens of thousands of hectares of GI does not come without cost and it requires the conversion of land that is now used otherwise. However, recent updates of several EU policies 


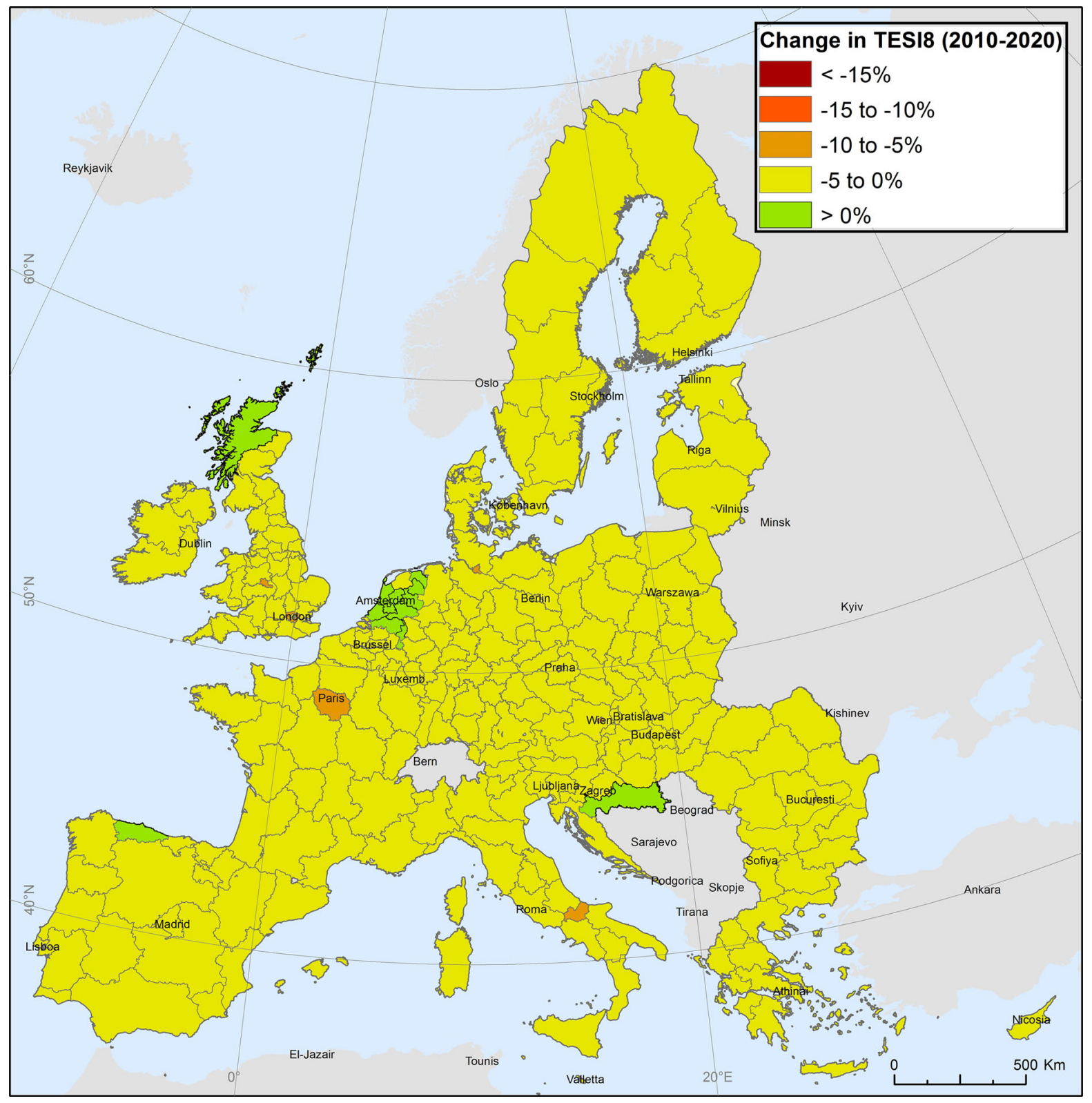

Fig. 5 Change (\%) in the total ecosystem services index expected for 2020 under the reference scenario for land use change relative to 2010

foresee the expansion of land that qualifies as GI. Here we discuss four main strands of land development, both in urban and rural areas, which take place at EU scale and which can contribute to a network of GI that supports biodiversity targets including the maintenance and enhancement of ecosystem services.

The establishment of Ecological Focus Areas (EFAs) under the new Common Agriculture Policy
(CAP 2014-2020) may contribute significantly to an expansion of the GI network in Europe. EFAs are areas in agricultural land covered by field margins, hedges, trees, fallow land, landscape features, biotopes, buffer strips, and afforested area. Under the new CAP regulation, at least $5 \%$ of the arable area of holdings with an arable area larger than 15 ha must be allocated to EFA. Such areas contribute to several ecosystem 


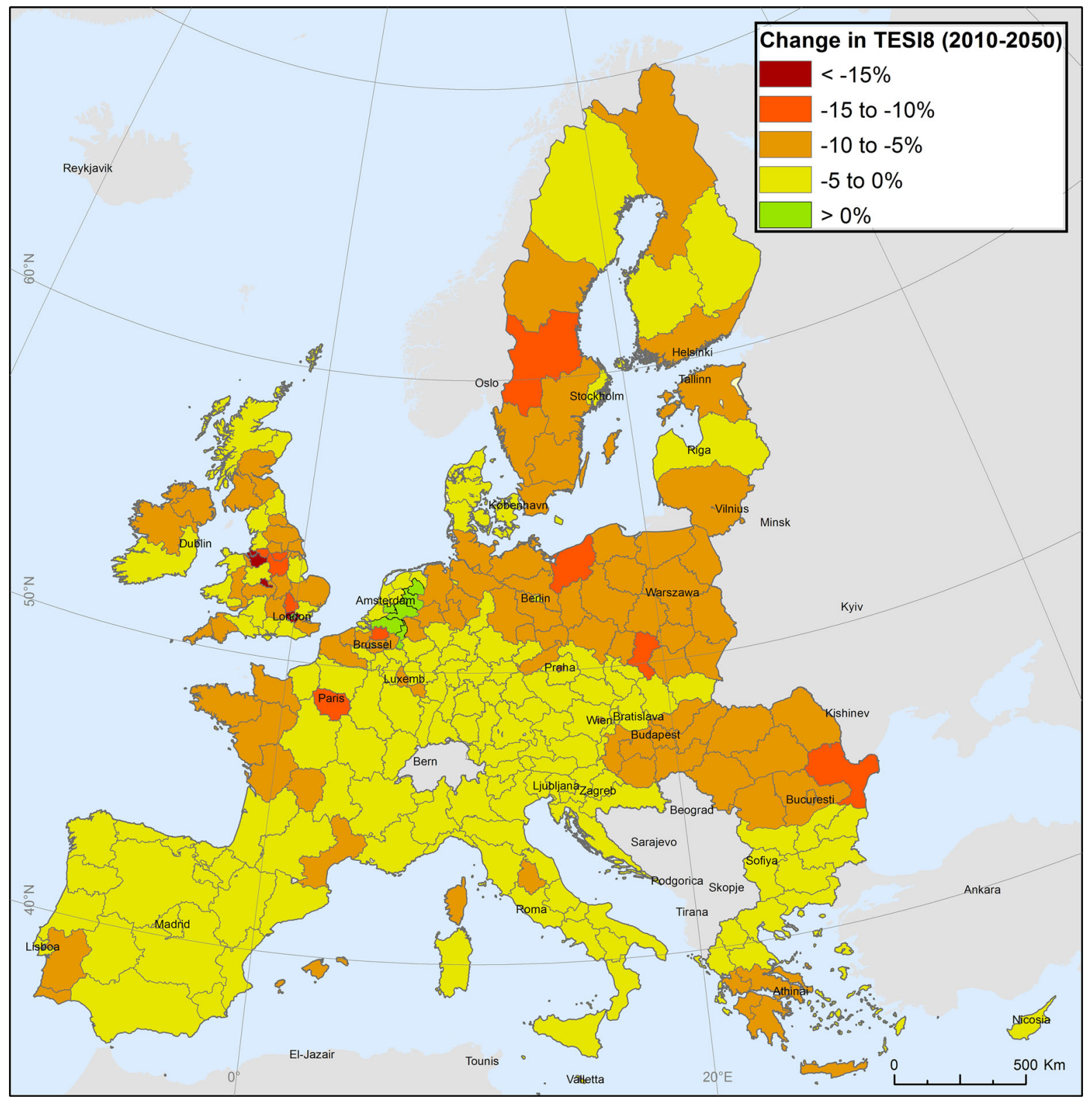

Fig. 6 Change (\%) in the total ecosystem services index expected for 2050 under the reference scenario for land use change relative to 2010

services, but in particular to pollination, biological control, soil erosion prevention, water quantity and water quality regulation; all of which are important to support sustainable agriculture (Bommarco et al. 2013).

Another important policy which is expected to contribute to the development of a GI network across Europe is set by the Convention of Biological Diversity (CBD), which requires under its Target 15 to restore $15 \%$ of degraded ecosystems. Following the adoption of the so called Aichi targets under the CBD, the EU biodiversity policy to 2020 explicitly links GI creation to the $15 \%$ target. Besides land conversion and habitat destruction, the loss of connectivity between habitats and ecosystems is a major cause of biodiversity loss and ecosystem degradation. Reconnecting fragmented landscapes and nature reserves through GI elements such as green corridors, 


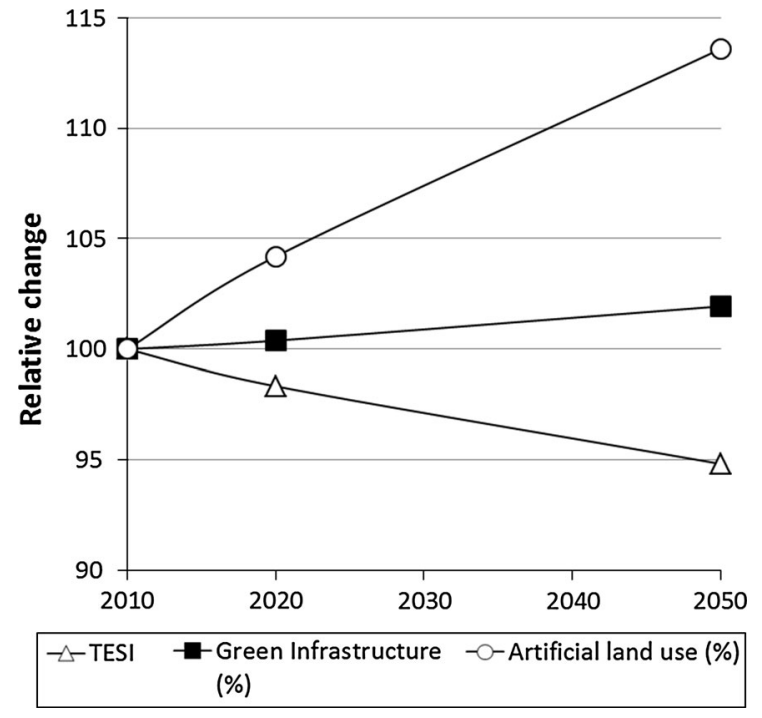

Fig. 7 Change in TESI8, green infrastructure and artificial land use aggregated at EU scale according to the reference scenario

Table 3 Regression results and diagnostics

\begin{tabular}{lclrl}
\hline $\begin{array}{l}\text { Regression } \\
\text { coefficients }\end{array}$ & Coefficient & SD & $t$ & $p$ \\
\hline a (intercept) & 2.3367 & 0.068 & 34.5 & $<0.05$ \\
b (slope of GI & 0.0093 & 0.001 & 7.9 & $<0.05$ \\
$\quad$ in Eq. 3) & & & & \\
c (slope of AS & -0.0206 & 0.002 & -11.7 & $<0.05$ \\
$\quad$ in Eq. 3) & & & & \\
$\mathrm{R}^{2}$ & 0.58 & & & \\
$\mathrm{~F}$ & 179.1 & & & \\
$p$ & $<0.05$ & & &
\end{tabular}

Multiple linear regression based on Eq. 3 using data for 267 NUTS 2 regions in Europe

ecoducts, or ecological buffer zones around natural reserves will be essential to meet the biodiversity targets and to provide a network along which species, some of which deliver key ecosystem services, can move and adapt under a changing climate.

Thirdly, some observers advocate that the rewilding of abandoned landscapes in remote areas in Europe as another, as an additional way to enhance the aggregate delivery of ecosystem services at EU scale (Navarro and Pereira 2012). Contemporary rewilding is the restoration of interconnected core wilderness areas based on the regulatory roles of keystone species and large predators (Soulé and Noss 1998). Navarro and

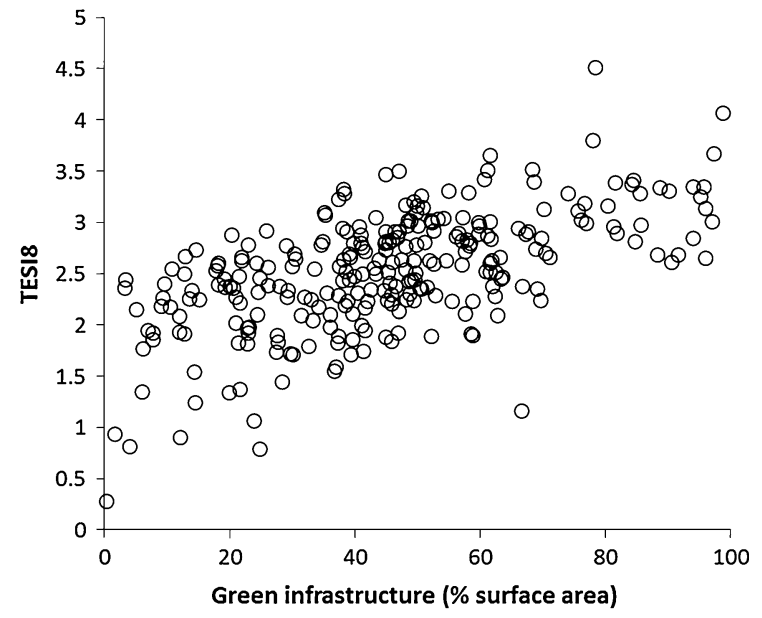

Fig. 8 Relationship between the total ecosystem services index (TESI8) and green infrastructure

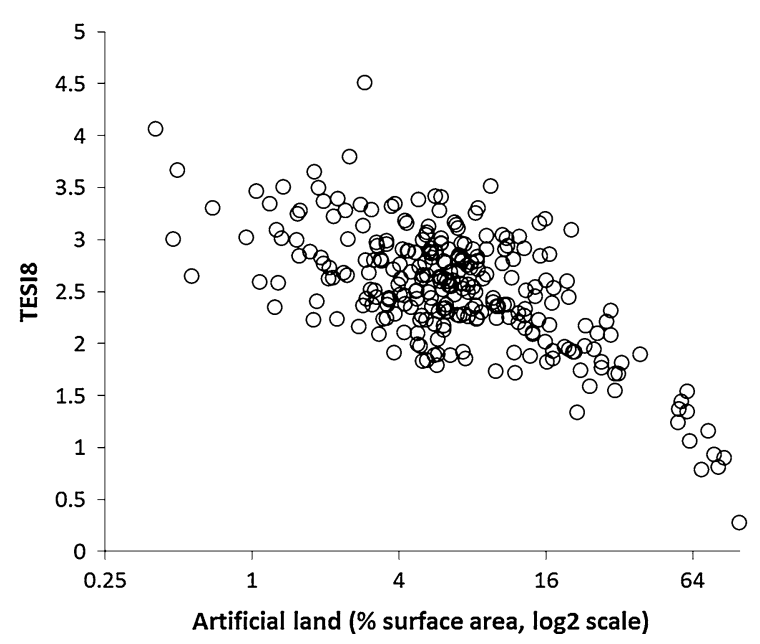

Fig. 9 Relationship between the total ecosystem services index (TESI8) and artificial land

Pereira (2012) examine the benefits and challenges of rewilding and report in particular enhanced cultural services such as wild-life based tourism and increased regulating ecosystem services related to the carbon and water cycles. Where desirable, rewilding represents thus another option to, at least partially, find space for the implementation of GI in Europe, provided that possible conflicts which arise from overlap between human activity and wildlife are carefully considered.

A fourth and increasingly important area for consideration of GI development is the city and its 
surrounding landscape. In cities GI is linked to human health through the ecosystem services that are provided by urban parks, peri-urban green belts, or forests and semi-natural areas which surrounds cities. Health benefits derived from urban and peri-urban GI include increased air quality, regulation of the micro-climate through the cooling effects of vegetation, recreation, psychological health and mental well-being. At regional scale peri-urban GI contributes to recreation while providing other regulating services such as water regulation, flood risk prevention and carbon sequestration (Gómez-Baggethun and Barton 2013).

Besides the availability of land, also the cost associated with the creation and maintenance of large surface areas of GI to enhance ecosystem services is a critical factor. Implementing GI across the EU requires considerable investments. Estimates for 90 individual GI projects range from $€ 0.5$ to $€ 5$ million (Naumann et al. 2011) while these authors found that five very large projects had budgets over $€ 25$ million. Financing projects of this scale requires investments of large funding bodies. At EU scale, funding of this size is only available through the cohesion policy or the European Investment Bank. Using such funds for large scale restoration projects and deployment of GI requires demonstrating that investments do not only contribute to environmental policy targets but also deliver jobs and create economic growth through innovation. Clearly, GI delivers value through the ecosystem services they provide and scientific research continues to provide more robust estimates of such values (de Groot et al. 2012). A convincing case for urban GI is presented by Vandermeulen et al. (2011) who assessed costs and benefits of a green belt investment around a Belgian city. Costs considered by this approach include land purchasing costs, design and construction costs and maintenance costs of the infrastructure, whilst benefits include production and regulating ecosystem services such as air quality improvement and climate change mitigation, as well as improved health from cycling, reduced accident risks, as well as recreational benefits. At the regional scale, the project was expected to deliver additional benefits that were more than twice as high as the costs. Going to the global scale, a review of over 200 studies by De Groot et al. (2013) demonstrated that even under the worst case scenarios (assuming $100 \%$ cost and only $30 \%$ benefit) in six of the nine biomes restoration yielded net economic benefits, providing a financial profit. Importantly, and not considered by De Groot et al. (2013), economies of scale-the decreasing cost per unit output with increasing scale-may be possible to safe costs on large scale restoration (Menz et al. 2013), for instance by sharing fixed costs for project management, knowledge generation and maintenance of restoration infrastructure such as seed banks or equipment. In addition, expected job creation is a powerful argument to convince budget holders for investment in GI projects. Edwards et al. (2013) present evidence that job creation per million US\$ spent on nature conservation and restoration is considerably higher than for other traditional industries including coal, gas, and nuclear energy generation.

\section{Conclusion}

The increasing concentration of people in cities presents both opportunities and challenges. Cities are poles of growth and innovation (Bettencourt et al. 2007) but growing cities depend on a sustained supply of life-supporting ecosystem services (Ervin et al. 2012). We concluded that in Europe urbanisation should be accompanied with additional growth of GI which provides services that are as important as other urban infrastructure. To offset land losses due to urbanisation and to account for additional demands of increasing population for resources, we concluded that substantial investments in the development of GI are needed. This requires smarter use of available land and demonstrating that investments in GI may lead to additional benefits for the society as a whole.

Acknowledgments The LUISA platform is funded under the institutional working program of the Joint Research Centre. The development of ESTIMAP is part of the OpenNESS project and has received funding from the European Union's Seventh Programme for Research, technological development and demonstration under Grant agreement No. 308428.

\section{References}

Batista e Silva F, Lavalle C, Jacobs-Crisioni C, Barranco R, Zulian G, Maes J, Baranzelli C, Perpiña C, Vandecasteele I, Ustaoglu E, Barbosa A, Mubareka S (2013) Direct and indirect land use impacts of the eu cohesion policy. Assessment with the Land Use Modelling Platform. EUR 26460. Publications Office of the European Union, Luxembourg 
Batista e Silva F, Koomen E, Diogo V, Lavalle C (2014) Estimating demand for industrial and commercial land use given economic forecasts. PLoS One 9(3):e91991

Beelen R, Hoek G, Pebesma E, Vienneau D, de Hoogh K, Briggs DJ (2009) Mapping of background air pollution at a fine spatial scale across the European Union. Sci Total Environ 407(6):1852-1867

Benedict MA, MacMahon ET (2002) Green infrastructure: smart conservation for the 21 st century. Renew Resour J 20(3):12-17

Benjamin K, Domon G, Bouchard A (2005) Vegetation composition and succession of abandoned farmland: effects of ecological. Hist Spat Factors Landsc Ecol 20(6):627-647

Bettencourt LMA, Lobo J, Helbing D, Kühnert C, West GB (2007) Growth, innovation, scaling, and the pace of life in cities. Proc Natl Acad Sci USA 104(17):7301-7306

Bommarco R, Kleijn D, Potts SG (2013) Ecological intensification: harnessing ecosystem services for food security. Trends Ecol Evol 28(4):230-238

Böttcher H, Verkerk PJ, Gusti M, HavlÍk P, Grassi G (2012) Projection of the future $\mathrm{EU}$ forest $\mathrm{CO}_{2}$ sink as affected by recent bioenergy policies using two advanced forest management models. GCB Bioenergy 4(6):773-783

Britz W, Witzke HP (2008) CAPRI Model Documentation 2008: Version 2. Institute for Food and Resource Economics, University of Bonn, Bonn

Cardinale BJ (2011) Biodiversity improves water quality through niche partitioning. Nature 472(7341):86-91

Cardinale BJ, Matulich KL, Hooper DU, Byrnes JE, Duffy E, Gamfeldt L, Balvanera P, O'Connor MI, Gonzalez A (2011) The functional role of producer diversity in ecosystems. Am J Bot 98(3):572-592

De Groot R, Brander L, van der Ploeg S, Costanza R, Bernard F, Braat L, Christie M, Crossman N, Ghermandi A, Hein L, Hussain S, Kumar P, McVittie A, Portela R, Rodriguez LC, ten Brink P, van Beukering, P (2012) Global estimates of the value of ecosystems and their services in monetary units. Ecosyst Serv 1(1):50-61

De Groot RS, Blignaut J, Van Der Ploeg S, Aronson J, Elmqvist T, Farley J (2013) Benefits of investing in ecosystem restoration. Conserv Biol 27(6):1286-1293

Dick J, Maes J, Smith RI, Paracchini ML, Zulian G (2014) Cross-scale analysis of ecosystem services identified and assessed at local and European level. Ecol Ind 38:20-30

Edwards PET, Sutton-Grier AE, Coyle GE (2013) Investing in nature: restoring coastal habitat blue infrastructure and green job creation. Mar Policy 38:65-71

Ervin D, Brown D, Chang H, Dujon V, Granek E, Shandas V, Yeakley, A (2012) Growing cities depend on ecosystem services. Solutions 2(6):74-86

European Commission (2010a) EU energy trends to 2030. Publications office of the European Union, Luxembourg

European Commission (2010b) Europe 2020: a strategy for smart, sustainable and inclusive growth. COM(2010)2020. Brussels

European Commission (2011a) Our life insurance, our natural capital: an EU biodiversity strategy to 2020. COM(2011)244. Brussels

European Commission (2011b) Impact assessment accompanying the Energy Roadmap 2050. SEC(2011)1566. Brussels
European Commission (2011c) Energy Roadmap 2050. COM(2011)885. Brussels

European Commission (2011d) The 2012 ageing report. Underlying assumptions and projection methodologies. Brussels

European Commission (2012) Green infrastructure (GI)enhancing Europe's Natural Capital. COM(2013)249. Brussels

European Commission (2013) EU energy, transport and GHG emissions. Trends to 2050. Reference Scenario 2013. Publications Office of the European Union, Luxembourg

European Environment Agency (2011) Green infrastructure and territorial cohesion. Technical Report 2011/18. Copenhagen

European Parliament and Council (2009a) Directive 2009/28/ EC of the European Parliament and of the Council of 23 April 2009 on the promotion of the use of energy from renewable sources and amending and subsequently repealing directives 2001/77/EC and 2003/30/EC. Off J Eur Union L140:16-62

European Parliament and Council (2009b) Decision no 406/2009/EC of the European Parliament and of the Council of 23 April 2009 on the effort of member states to reduce their greenhouse gas emissions to meet the Community's greenhouse gas emission reduction commitments up to 2020. Off J Eur Union L140:136-148

Foley JA, DeFries R, Asner GP, Barford C, Bonan G, Carpenter SR, Chapin FS, Coe MT, Daily GC, Gibbs HK, Helkowski JH, Holloway T, Howard EA, Kucharik CJ, Monfreda C, Patz JA, Prentice IC, Ramankutty N, Snyder PK (2005) Global consequences of land use. Science 309(5734): $570-574$

García-Llorente M, Martín-López B, Iniesta-Arandia I, LópezSantiago CA, Aguilera PA, Montes C (2012) The role of multi-functionality in social preferences toward semi-arid rural landscapes: an ecosystem service approach. Environ Sci Policy 19-20:136-146

Geneletti D (2012) Assessing the impact of alternative land-use zoning policies on future ecosystem services. Environ Impact Assess Rev

Gómez-Baggethun E, Barton DN (2013) Classifying and valuing ecosystem services for urban planning. Ecol Econ 86:235-245

Haines-Young R, Potschin M (2013) Common International Classification of Ecosystem Services (CICES): consultation on version 4, August-December 2012. EEA Framework Contract No EEA/IEA/09/003

Hector A, Bagchi R (2007) Biodiversity and ecosystem multifunctionality. Nature 448(7150):188-190

Hiederer R, Lopes Barbosa A, Baranzelli C, Grassi G, Lavalle C (2013) IPCC Tier 1 method for estimating C-Stocks of mineral soils. Applied to Modeled Land Use Change 2010-2050. European Commission, Joint Research Centre, Ispra. JRC87923

Hilferink M, Rietveld P (1999) Land use scanner: an integrated GIS based model for long term projections of land use in urban and rural areas. J Geogr Syst 1:155-177

Isbell F, Calcagno V, Hector A, Connolly J, Harpole WS, Reich PB, Scherer-Lorenzen M, Schmid B, Tilman D, Van Ruijven J, Weigelt A, Wilsey BJ, Zavaleta ES, Loreau M 
(2011) High plant diversity is needed to maintain ecosystem services. Nature 477(7363):199-202

Koomen E, Hilferink M, van Beurden JB (2011) Introducing land use scanner. In: Koomen E, van Beurden JB (eds) Land-use modelling in planning practice. The GeoJournal Library. Springer, New York

Lafortezza R, Davies C, Sanesi G, Konijnendijk C (2013) Green infrastructure as a tool to support spatial planning in European urban regions. iForest Biogeosci For 6(3):102-108

Lambin EF, Meyfroidt P (2011) Global land use change, economic globalization, and the looming land scarcity. Proc Natl Acad Sci USA 108(9):3465-3472

Lavalle C, Baranzelli C, Batista e Silva F, Mubareka S, Rocha Gomes C, Koomen E, Hilferink M (2011a) A high resolution land use/cover modelling framework for Europe. In: ICCSA 2011, Part I, LNCS 6782, pp 60-75

Lavalle C, Mubareka S, Perpiña C, Jacobs-Crisioni C, Baranzelli C, Batista e Silva F, Vandecasteele I (2013) Configuration of a reference scenario for the land use modelling platform. EUR 26050. Publications Office of the European Union, Luxembourg

Liquete C, Zulian G, Delgado I, Stips A, Maes J (2013) Assessment of coastal protection as an ecosystem service in Europe. Ecol Ind 30:205-217

Lovell ST, Taylor JR (2013) Supplying urban ecosystem services through multifunctional green infrastructure in the United States. Landscape Ecol 28(8):1447-1463

MA (2005) Ecosystems and human well-being: biodiversity synthesis. Millennium Ecosystem Assessment. World Resources Institute, Washington, DC

Mace GM, Norris K, Fitter AH (2012) Biodiversity and ecosystem services: a multilayered relationship. Trends Ecol Evol 27(1):19-26

Maes J, Paracchini MP, Zulian G, Alkemade R (2012) Synergies and trade-offs between ecosystem service supply, biodiversity and habitat conservation status in Europe. Biol Conserv 155:1-12

Maes J, Hauck J, Paracchini ML, Ratamäki O, Hutchins M, Termansen M, Furman E, Pérez-Soba M, Braat L, Bidoglio G (2013a) Mainstreaming ecosystem services into EU policy. Curr Opin Environ Sustain 5(1):128-134

Maes J, Teller A, Erhard M, Liquete C, Braat L, Berry P, Egoh B, Puydarrieux P,Fiorina C, Santos F, Paracchini ML, Keune H, Wittmer H, Hauck J, Fiala I,Verburg PH, Condé S, Schägner JP, San Miguel J, Estreguil C, Ostermann O, Barredo JI, Pereira HM, Stott A, Laporte V, Meiner A, Olah B, Royo Gelabert E, Spyropoulou R, Petersen JE, Maguire C, Zal N, Achilleos E, Rubin A, Ledoux L, Brown C, Raes C, Jacobs S, Vandewalle M, Connor D, Bidoglio G (2013b) Mapping and assessment of ecosystems and their services. An analytical framework for ecosystem assessments under action 5 of the EU biodiversity strategy to 2020. Publications Office of the European Union, Luxembourg

Menz MHM, Dixon KW, Hobbs RJ (2013) Hurdles and opportunities for landscape-scale restoration. Science 339(6119):526-527

Metzger MJ, Rounsevell MDA, Acosta-Michlik L, Leemans R, Schröter D (2006) The vulnerability of ecosystem services to land use change. Agric Ecosyst Environ 114(1):69-85
Naeem S, Duffy JE, Zavaleta E (2012) The functions of biological diversity in an age of extinction. Science 336(6087):1401-1406

Naumann S, McKenna D, Kaphengst T, Pieterse M, Rayment M (2011) Design, implementation and cost elements of green infrastructure projects. Final Report to the European Commission, DG Environment, Contract 070301/2010/ 577182/ETU/F.1. Ecologic Institute and GHK Consulting

Navarro LM, Pereira HM (2012) Rewilding abandoned landscapes in Europe. Ecosystems 15(6):900-912

Nowak DJ, Crane DE, Stevens JC (2006) Air pollution removal by urban trees and shrubs in the United States. Urban For Urban Green 4(3-4):115-123

Panagos P, Meusburger K, Alewell C, Montanarella L (2012) Soil erodibility estimation using LUCAS point survey data of Europe. Environ Model Softw 30:143-145

Paracchini ML, Petersen JR, Hoogeveen Y, Bamps, Burfield I, van Swaay C (2008) High Nature Value Farmland in Europe. An estimate of the distribution patterns on the basis of land cover and biodiversity data. EUR 23480 EN. Publications Office of the European Union, Luxembourg

Paracchini ML, Zulian G, Kopperoinen L, Maes J, Schägner JP, Termansen M, Zandersen M, Perez-Soba M, Scholefield PA, Bidoglio G (2014) Mapping cultural ecosystem services: A framework to assess thepotential for outdoor recreation across the EU. Ecol Ind 45:371-385

Pataki DE, Carreiro MM, Cherrier J, Grulke NE, Jennings V, Pincetl S, Pouyat RV, Whitlow TH, Zipperer WC (2011) Coupling biogeochemical cycles in urban environments: ecosystem services, green solutions, and misconceptions. Front Ecol Environ 9(1):27-36

Raudsepp-Hearne C, Peterson GD, Bennett EM (2010) Ecosystem service bundles for analyzing tradeoffs in diverse landscapes. Proc Natl Acad Sci USA 107(11):5242-5247

Soulé M, Noss R (1998) Rewilding and biodiversity: complementary goals for continental conservation. Wild Earth 8(3):19-28

Ten Brink P, Badura T, Bassi S, Daly E, Dickie I, Ding H, Gantioler S, Gerdes H, Kettunen M, Lago M, Lang S, Markandya A, Nunes PALD, Pieterse M, Rayment M, Tinch R (2011). Estimating the overall economic value of the benefits provided by the Natura 2000 Network. Final Report to the European Commission, DG Environment on Contract ENV.B.2/SER/2008/0038. Institute for European Environmental Policy/GHK/Ecologic, Brussels

Tzoulas K, Korpela K, Venn S, Yli-Pelkonen V, Kaźmierczak A, Niemela J, James P (2007) Promoting ecosystem and human health in urban areas using Green Infrastructure: a literature review. Landsc Urban Plan 81(3):167-178

Vandecasteele I, Bianchi A, Batista e Silva F, Lavalle C, Batelaan O (2014) Mapping current and future European public water withdrawals and consumption. Hydrol Earth Syst Sci 18:407-416

Vandermeulen V, Verspecht A, Vermeire B, Van Huylenbroeck G, Gellynck X (2011) The use of economic valuation to create public support for green infrastructure investments in urban areas. Landsc Urban Plan 103(2):198-206

Veldkamp A, Fresco LO (1996) CLUE-CR: an integrated multiscale model to simulate land use change scenarios in Costa Rica. Ecol Model 91(1-3):231-248 
Verburg PH, Overmars KP (2009) Combining top-down and bottom-up dynamics in land use modeling: exploring the future of abandoned farmlands in Europe with the DynaCLUE model. Landscape Ecol 24(9):1167-1181

Verburg PH, Rounsevell MDA, Veldkamp A (2006) Scenariobased studies of future land use in Europe. Agric Ecosyst Environ 114(1): 1-6

Vogt P (2012) User guide for GUIDOS [online]. European Commission Joint Research Center. Available from: http:// forest.jrc.ec.europa.eu/download/software/guidos. Accessed 12 Apr 2012

Wriedt G, Bouraoui F (2009) Towards a general water balance assessment of Europe. EUR 23966 EN. Publications Office of the European Union, Luxembourg
Paracchini ML, Zulian G, Kopperoinen L, Maes J; Schaegner P, Termansen M, Zandersen M, Peres-Soba M, Scholefield P (submitted) Mapping cultural ecosystem services: the case of outdoor recreation. Ecol Indic (third review)

Zulian G, Paracchini ML, Maes J, Liquete C (2013a) ESTIMAP: Ecosystem services mapping at European scale. EUR 26474. Publications Office of the European Union, Luxembourg

Zulian G, Maes J, Paracchini M (2013b) Linking land cover data and crop yields for mapping and assessment of pollination services in Europe. Land 2(3):472-492 